\title{
Paleofluid evolution of the fractured basalt hydrocarbon reservoir in the Üllés-Ruzsa-Bordány area, SE Hungary
}

\author{
Barbara Szabó, Tivadar M. Tóth, Félix Schubert \\ Department of Mineralogy, Geochemistry and Petrology \\ University of Szeged, Szeged
}

\begin{abstract}
Volcanic successions of the Kecel Basalt Formation (KBF) occur in the southern part of the Pannonian Basin. As a result of periodic submarine eruptions, the basaltic and pyroclastic rock horizons were intercalated with layers of the Late Miocene Endrod Marl Formation, which is regarded as one of the most important hydrocarbon source rocks in the area. The KBF was discovered through almost 30 wells between 2,200 and 2,900 meters of depth. Due to the high fracture porosity, some parts of the formation show good reservoir characteristics and act as important migration pathways of hydrocarbon-bearing fluids. Since the reservoir is presumably fracture-controlled, this study concentrates on the evolution of fractures crosscutting the rock body. Based on textural and mineralogical features, four distinct vein types can be distinguished, of which the first three types are discussed in this paper. Beside calcite, quartz, feldspar, and chlorite, the veins are cemented by various zeolite minerals. The vertical dimension of the dominant zeolite zone indicates the burial-diagenetic type of zeolite zonation and suggests subsidence of the subaqueous basalt after formation.
\end{abstract}

Key words: fractured hydrocarbon reservoir, metabasalt, Pannonian Basin, vein microstructure, microthermometry, zeolite zones

\section{Introduction}

The volcanic and pyroclastic rocks of the Kecel Basalt Formation are the result of the extensive Lower Pannonian volcanic activity in the southern part of the Pannonian Basin. This formation is unique due to the presence of reservoir-scale petroleum accumulations within the fractured volcanic succession. Although it has been identified from several boreholes and is of economic importance, the

Addresses: B. Szabó, T. M. Tóth, F. Schubert: H-6701 Szeged, P.O. Box 651, Hungary, e-mail: szabob@geo.u-szeged.hu

Received: April 30, 2009; accepted: August 4, 2009 
evolution of the rock body and its fracture system has not yet been studied in detail. Only a few studies have focused on the rock (Cserepesné Meszéna 1978; Pap 1983; Balázs and Nusszer 1987), and only one thesis has focused specifically on the cementation of the vesicles and fractures (Rappensberger 1991). Rappensberger (1991) identified crystals of several cement mineral phases by SEM and optical microscope (saponite, illite-nontronite, laumontite, heulandite, analcime, levyne, yugawaralite), but he focused mostly on the vesicles, not on the veins, and he did not deal with questions of genetics.

The aim of this study is to provide new information about the mineralization of the vesicles and veins during and after the post-volcanic alteration of the reservoir. We do not deal with genetic circumstances of the host basaltic rock body and its metasomatic alteration synchronous with the volcanic activity.

\section{Geologic setting}

In the 1970s and 1980s, several hydrocarbon exploration boreholes were drilled in the southern part of the Pannonian Basin, in SE Hungary. Some of them penetrated intensely altered volcanic rocks named Kecel Basalt Formation (KBF) after the location of the most extensive and thickest series of the volcanic formation (Császár 1997). The Late Miocene to Lower Pannonian basaltic rocks were drilled in the area of Szank, Kiskunhalas, Sándorfalva, Pusztamérges, Üllés, Ruzsa and Bordány by several wells (Cserepesné Meszéna 1978; Pap 1983; Balázs and Nusszer 1987). The stratigraphic thickness of the volcanic formation varies from a few to more than 600 meters across the province. The formation consists of pyroclastic and lava rocks interbedded with up to several hundred meter-thick layers of the Endrod Marl Formation (EMF). The interlayered and overlying strata of the Tótkomlós Calcareous Marl Member of the EMF include fossils (referred to Kőváry and Széles in Balázs and Nusszer 1987); paleontological evidence shows that the age of the basalt must be between 8 and $11.6 \mathrm{Ma}$ (Magyar et al. 2004). The results are in agreement with the whole rock $\mathrm{K} / \mathrm{Ar}$ radiometric ages, determined as $8.13 \pm 0.71 \mathrm{Ma}$ from Kecel-1, as 9.61 $\pm 0.38 \mathrm{Ma}$ from Kiskunhalas-Ny-3 and as 10.4 \pm 1.8 Ma from the Ruzsa-4 wells (Cserepesné Meszéna 1978; Pap 1983; Balázs and Nusszer 1987).

The present study concentrates on the successions of KBF in the area of Üllés, Ruzsa and Bordány (Fig. 1). Pap (1983) and Balázs and Nusszer (1987) defined similar petrographic characteristics of the volcanic rocks. The pyroclastic and lava rocks are intercalated and overlain by Lower Pannonian calcareous marl and argillaceous marl (EMF), and underlain by Badenian sandstone-siltstone (Békési Formation). In the underlying sandstone bed, the authors identified basaltic dikes. The volcanic strata consist to a large extent of pyroclastics with lesser lava rocks, including tuff layers and marl units in the lower part. In addition to the intercalated calcareous marl, the lava rock locally contains spheroid marl inclusions (Pap 1983; Balázs and Nusszer 1987). The stratigraphic position of the 


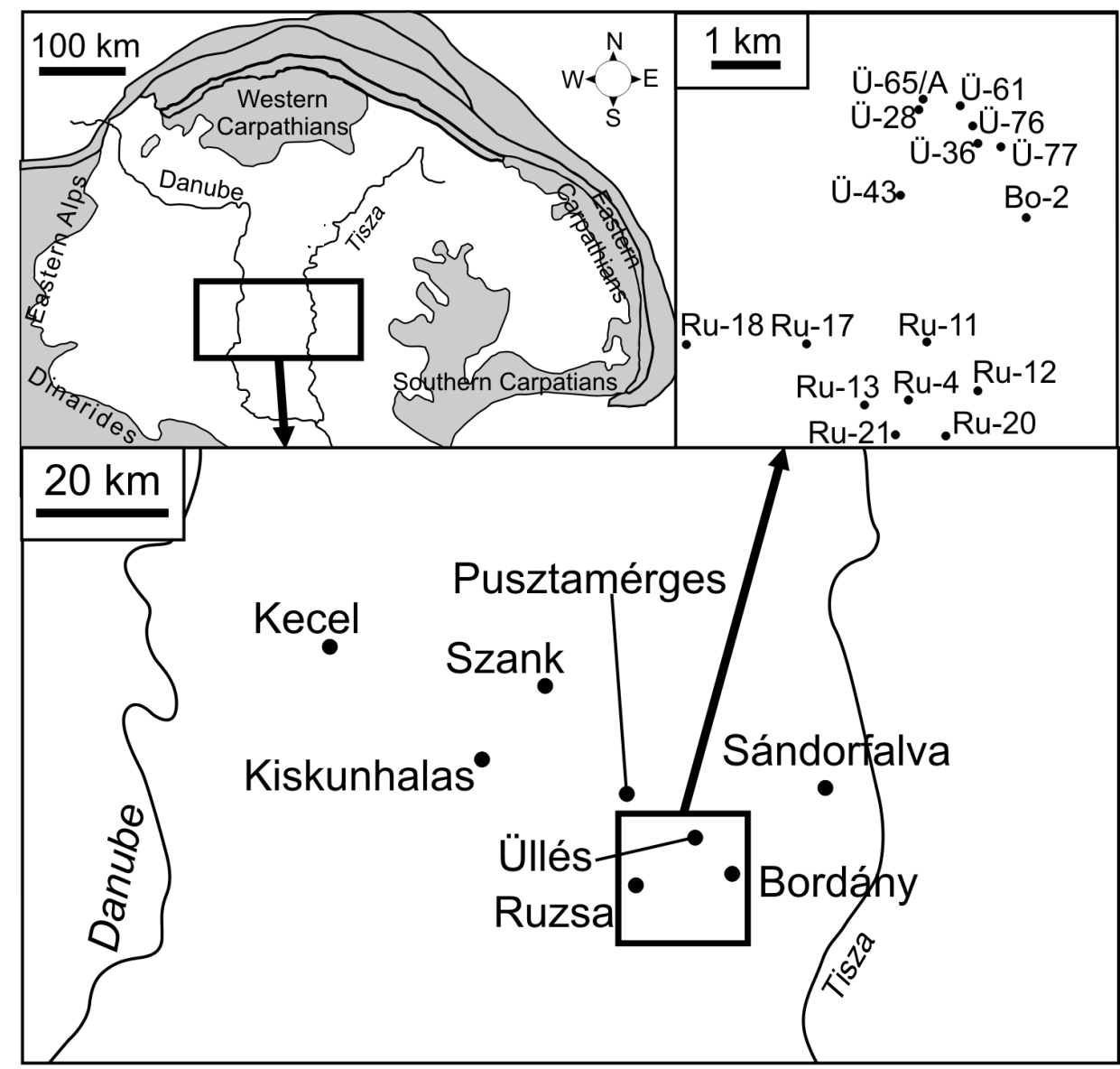

Fig. 1

Location of the study area in the Pannonian Basin. Insets: Occurrence of Kecel Basalt Formation. Studied wells in Üllés-Ruzsa-Bordány area

volcanic rocks is well presented by Pap (1983) and Gajdos et al. (1983). Although the total thickness of the volcanic succession is not known everywhere, it was penetrated over $500 \mathrm{~m}$ in some wells (Kecel-1: $540 \mathrm{~m}$, Kecel-2: $616 \mathrm{~m}$ ).

\section{Samples and methods}

The Kecel Basalt Formation has been explored by almost 30 wells in the area of Üllés, Ruzsa and Bordány. The volcanic rocks were penetrated between 2,200 and 2,900 meters. For petrological studies, there are core samples from 15 wells, and cuttings from one well (Fig. 1) (Table 1). Of the core samples, some were chosen 
for further investigation as representative mainly of fracture cementation, and of rock texture in the second place. The macroscopic observations were carried out to explore the very basic textural characteristics of the rocks, the relationship of veins and vesicles, the paragenesis and spatial relationships of the fracture-filling minerals.

Table 1

Well data from Üllés-Ruzsa-Bordány area

\begin{tabular}{|c|c|c|c|c|c|}
\hline Well & $\begin{array}{l}M D^{*} \text { of } K B F \\
(\mathrm{~m})\end{array}$ & $\begin{array}{l}\text { TVD }{ }^{* *} \text { of } \\
\text { KBF (m) }\end{array}$ & $\begin{array}{l}\text { Depth of core } \\
\text { samples }(m)\end{array}$ & Rock type & Fracture-fillings \\
\hline Bo-2 & $2517-2653$ & n. d. $^{* * *}$ & $2525-2531$ & $\begin{array}{l}\text { basalt tuff, basalt } \\
\text { agglomerate }\end{array}$ & $\begin{array}{l}\text { Weathered volcanic } \\
\text { material, calcite, } \\
\text { heulandite }\end{array}$ \\
\hline Ru-4 & $2655-2829$ & n. d. & $2657-2665$ & $\begin{array}{l}\text { basalt tuff, basalt } \\
\text { agglomerate }\end{array}$ & $\begin{array}{l}\text { Quartz, laumontite, } \\
\text { calcite }\end{array}$ \\
\hline Ru-11 & $2645-2783$ & $2645-2783$ & $2705-2711$ & $\begin{array}{l}\text { basalt, basalt } \\
\text { agglomerate }\end{array}$ & Laumontite, calcite \\
\hline Ru-12 & $2727-2893$ & n. d. & \begin{tabular}{|l|} 
1. $2731-2741$ \\
2. $2805-2814$
\end{tabular} & $\begin{array}{l}\text { basalt tuff, basalt } \\
\text { agglomerate }\end{array}$ & Laumontite, calcite \\
\hline Ru-13 & $2708-2843$ & n. d. & $2713-2727$ & $\begin{array}{l}\text { basalt tuff, basalt } \\
\text { agglomerate }\end{array}$ & $\begin{array}{l}\text { Prehnite, chlorite, } \\
\text { laumontite, calcite }\end{array}$ \\
\hline Ru-17 & $2527-2546$ & $2527-2546$ & $2535-2541$ & $\begin{array}{l}\text { basalt tuff, basalt } \\
\text { agglomerate }\end{array}$ & Laumontite, calcite \\
\hline Ru-18 & 2683-2702 & $2683-2702$ & $2687-2695$ & $\begin{array}{l}\text { basalt } \\
\text { agglomerate + } \\
\text { marl }\end{array}$ & Calcite \\
\hline Ru-20 & $2749-2842$ & $2682-2701$ & $2753-2762$ & $\begin{array}{l}\text { basalt tuff, basalt } \\
\text { agglomerate }\end{array}$ & Laumontite, calcite \\
\hline Ru-21 & $2795-2893$ & $2795-2893$ & $2795-2803$ & $\begin{array}{l}\text { basalt tuff, basalt } \\
\text { agglomerate }\end{array}$ & $\begin{array}{l}\text { K-feldspar, chlorite, } \\
\text { quartz, albite, } \\
\text { calcite, weathered } \\
\text { volcanic material }\end{array}$ \\
\hline Ü-28 & $2217-2360$ & n. d. & $\begin{array}{l}\text { 1. } 2218-2221.5 \\
\text { 2. } 2342-2350\end{array}$ & $\begin{array}{l}\text { basalt, basalt } \\
\text { agglomerate }\end{array}$ & Calcite, laumontite \\
\hline Ü-36 & $2262-2448$ & $2261.5-2447$ & $\begin{array}{l}\text { 1. } 2263-2275 \\
\text { 2. } 2340-2357\end{array}$ & $\begin{array}{l}\text { basalt, basalt } \\
\text { agglomerate }\end{array}$ & $\begin{array}{l}\text { Prehnite, chlorite, } \\
\text { laumontite, } \\
\text { thomsonite, calcite }\end{array}$ \\
\hline Ü-61 & $2235-2360$ & $\begin{array}{l}2234.5- \\
2359.5\end{array}$ & $2238-2250$ & $\begin{array}{l}\text { basalt, basalt } \\
\text { agglomerate }+ \\
\text { marl }\end{array}$ & $\begin{array}{l}\text { K-feldspar, chlorite, } \\
\text { calcite, analcime, } \\
\text { mesolite, heulandite, } \\
\text { stilbite }\end{array}$ \\
\hline Ü65/A & $2264-2330$ & $2248-2313.5$ & drilling chips & basalt, basalt tuff & $\begin{array}{l}\text { Prehnite, chlorite, } \\
\text { laumontite, } \\
\text { analcime, heulandite }\end{array}$ \\
\hline Ü-76 & $2253-2402$ & n. d. & $2267-2279$ & $\begin{array}{l}\text { basalt tuff, basalt } \\
\text { agglomerate + } \\
\text { marl }\end{array}$ & Laumontite, calcite \\
\hline Ü-77 & $2398-2477$ & n. d. & $2446-2455$ & $\begin{array}{l}\text { basalt tuff, basalt } \\
\text { agglomerate }\end{array}$ & $\begin{array}{l}\text { Weathered volcanic } \\
\text { material, calcite, } \\
\text { laumontite }\end{array}$ \\
\hline
\end{tabular}

${ }^{*}$ measured depth, ${ }^{* *}$ true verified depth, ${ }^{* * *}$ no data 
Almost 100 thin sections were investigated during the microscopic studies. Petrography was performed on 58 covered thin sections from the collection of the Hungarian Oil and Gas Company (MOL Plc.), and further uncovered thin sections were prepared in the Department of Mineralogy, Geochemistry and Petrology at the University of Szeged for SEM and Raman microspectroscopic studies. Petrography was performed using an Olympus SZX7 binocular and Nikon FXA and Olympus BX-41 polarizing microscopes. Vein microtextures are reviewed following the nomenclature of Bons (2000) and Oliver and Bons (2001). Raman spectra of fracture-filling minerals and fluid inclusions were recorded in part with a Horiba Jobin Yvone spectrometer connected with an Olympus BX40 microscope (Technical University of Budapest), and with a Labram-type spectrometer connected to an Olympus U-D6RE microscope (University of Nantes) using $50 \times$ and $100 \times$ LWD lenses. The radiating laser source operated at $532 \mathrm{~nm}$ in the former and at $488 \mathrm{~nm}$ in the latter case. The acquisition time was chosen depending on the intensity of the signal, usually 10-30 seconds in the case of minerals and $60-100$ seconds in the case of fluid inclusions, accumulated 3-5 times.

Both the highly polished thin sections and the crushed rock surfaces were studied with a Hitachi S-4700 scanning electron microscope. An accelerating voltage of $15-20 \mathrm{kV}$ was used for taking BSE and SE images. EDS spectra were recorded on the solid inclusions of calcite in Type 2 and prehnite crystals from vesicles and Type 3 veins.

Representative slices were cut from the veins available for fluid inclusion studies. Fifteen double polished thick sections $(75-150 \mu \mathrm{m})$ were prepared from the cores. When necessary, the slices were impregnated by epoxy under vacuum at $40{ }^{\circ} \mathrm{C}$ for at least 24 hours. The preparation procedure was done following the instructions of Shepherd et al. (1985).

Prior to microthermometry, fluid inclusion petrography was carried out in order to classify fluid inclusion assemblages following the criteria of Goldstein and Reynolds (1994). Microthermometry was carried out using a Linkam THMSG-600 heating-freezing stage mounted on an Olympus BX-41 microscope using LWD lenses with $\times 100$ magnification. The stage was calibrated using synthetic fluid inclusions trapped in quartz with an opened sample container and covered with a silver lid at $-56.6,0.0$ and $374{ }^{\circ} \mathrm{C}$. The accuracy of the measurements was $\pm 0.1^{\circ} \mathrm{C}$ below and $\pm 1{ }^{\circ} \mathrm{C}$ above $0{ }^{\circ} \mathrm{C}$. The homogenization temperature was usually determined only with the cycling method (Goldstein and Reynolds 1994). The salinities of the aqueous inclusions are reported in mass \% of $\mathrm{NaCl}$ equivalent following the calculated values of Goldstein and Reynolds (1994). The salinities were calculated from the final ice melting temperatures $\mathrm{Tm}(\mathrm{Ice})$. The concentrations of methane in the methane-bearing inclusions are not known, so the possible effects of the dissolved methane and the methane-hydrate-clathrate to the salinity could not be taken into account. 
The salinities of the present study are therefore maximum values (Schubert et al. 2007).

Mineral chemistry measurements were made in the Eugen F. Stumpfl electron microprobe laboratory at the Montanuniversität Leoben with a JEOL JXA 8200 Superprobe. Quantitative analyses were carried out with a $10 \mathrm{nA}$ beam current and $15 \mathrm{kV}$ accelerating voltage. The beam diameter was $1 \mu \mathrm{m}$ and the accumulation time was $10 \mathrm{sec}$ for the peaks and $4 \mathrm{sec}$ for the background. The detection limit was $0.1-0.02 \%$ in the case of $\mathrm{Si}, \mathrm{Al}, \mathrm{Ti}, \mathrm{Fe}, \mathrm{Mg}, \mathrm{Ca}, \mathrm{Na}, \mathrm{K}$ and $\mathrm{Mn}$. International mineral standards were used to quantitatively interpret the elements. ZAF correction was used to correct each measurement. Chlorite formulae were calculated based on 28 oxygens and with $\mathrm{Fe}^{2+} / \mathrm{Fe}^{3+}$ calculated assuming full-site occupancy similar to those followed by Rivas-Sanchez et al. (2006) in a similar geologic system.

Computed Tomography (CT) offers the possibility of a deep textural and petrographic investigation of a core sample in a non-destructive way. The CT equipment uses $\mathrm{X}$-ray for recording, and the reconstructed image shows the beam-weakening quality of the sample in every voxel represented by a matrix of Hounsfield Units (HU). The calculated HU values can be visualized by gray-scale imaging. The core sample from the Üllés-36 well was put under vacuum for 6 hours and then saturated with water before the CT-measurement. The CT measurements were carried out on Siemens Somatom S40 Spiral CT equipment in the Diagnostic Institute in the University of Kaposvár. Scanning was performed in 2-mm steps.

The pressure-temperature (P-T) conditions of the observed equilibrium mineral assemblages can be calculated using the thermodynamic properties of the minerals (Holland and Powell 1998) using WinDomino Software (De Capitani and Brown 1987; De Capitani 1994). THERIAK modul calculates the minimum Gibbs energy assemblage at a given P-T point, and DOMINO modul does it for a given P-T area in the case of a chemically closed system.

The minerals in the present study are abbreviated according to Kretz (1983), except for mesolite.

\section{Results}

Host rock

In the study area the thickest series of volcanic rocks (186 meters) was penetrated by well Üllés-36. In the area of Ruzsa, the KBF was drilled between 2,500 and 2,900 meters, while in the Bordány-Üllés area basalt occurs between 2,200 and 2,650 meters (Table 1).

Based on macroscopic observations, the vast majority of the samples represent pyroclastic rocks, while lava rocks are subordinate and occur only in the area of Üllés and Bordány (Fig. 2a and b) (Table 1). The rounded lapilli of the pyroclastic rock samples have vitrophyric rims in places. Angular fragments from the 

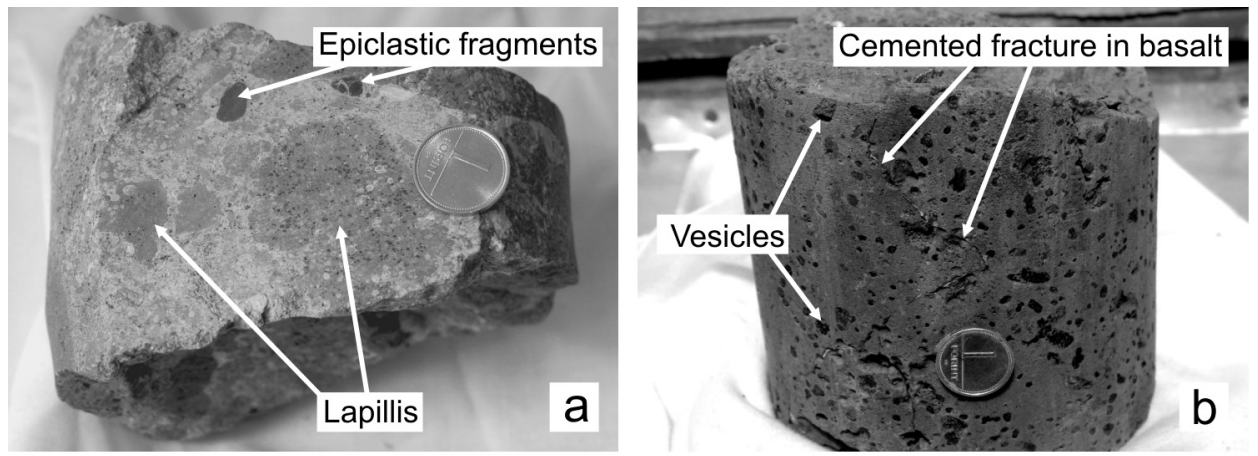

Fig. 2

Representative pyroclastic (a, Ruzsa-18) and lava rock (b, Üllés-36) cores
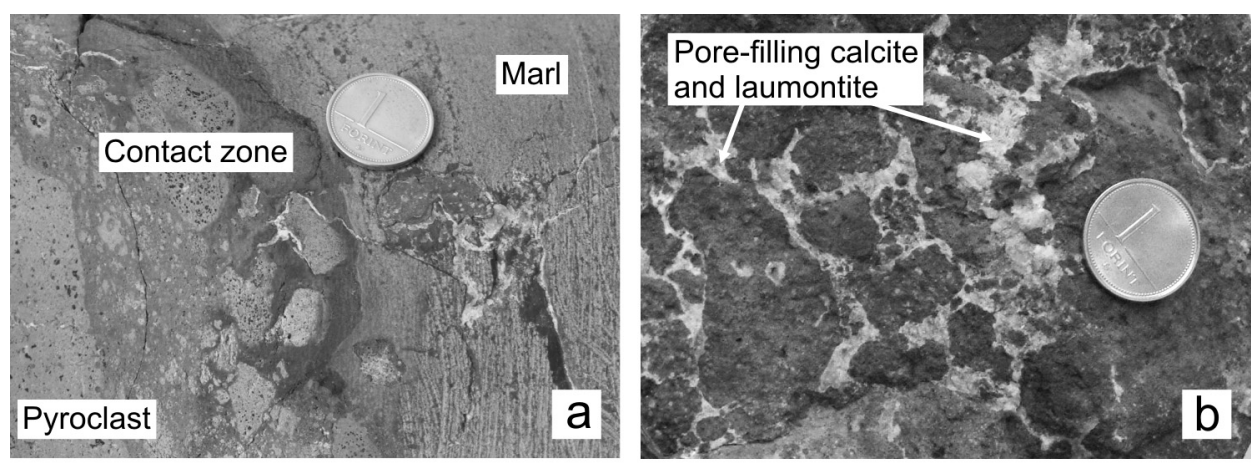

Fig. 3

a) In pyroclastic core samples pore space is typically filled by weathered volcanic material, occasionally mixed with marl along the contact zones (Ruzsa-18); b) At places the pore space among the lapillis is filled by minerals (Ruzsa-4)

intercalated marl layers are mixed up with lapilli in several places (Fig. 2a). Among the volcanic blocks, lapilli and smaller grains, the remnant space is filled with a fine fraction of volcanic ash and a clay mineral matrix (Fig. 2a). In the contact zones, the volcanic material is mixed with the fine fraction of the marine sediment (Fig. 3a). Occasionally, cement minerals (clay, carbonate and zeolite minerals) are precipitated among the lapilli and the smaller grains of the pyroclastic rocks (Fig. 3b). In places the volcanic rock contains marl inclusions, as was also observed by Balázs and Nusszer (1987). The loose, crumbly character and lighter color of the pyroclastic rocks and tuffs can be easily distinguished from the dark green, massive lava rocks. The lapilli and blocks of pyroclastic rocks and the lava rock samples are rich in vesicles and amigdaloids. Based on microscopic observations the texture of the lava rock is variolitic, spherulitic with phenocrysts and microphenocrysts of plagioclase as well as altered amphibole and pyroxene crystals (Fig. 4a and b). In some thin sections high limonite content 

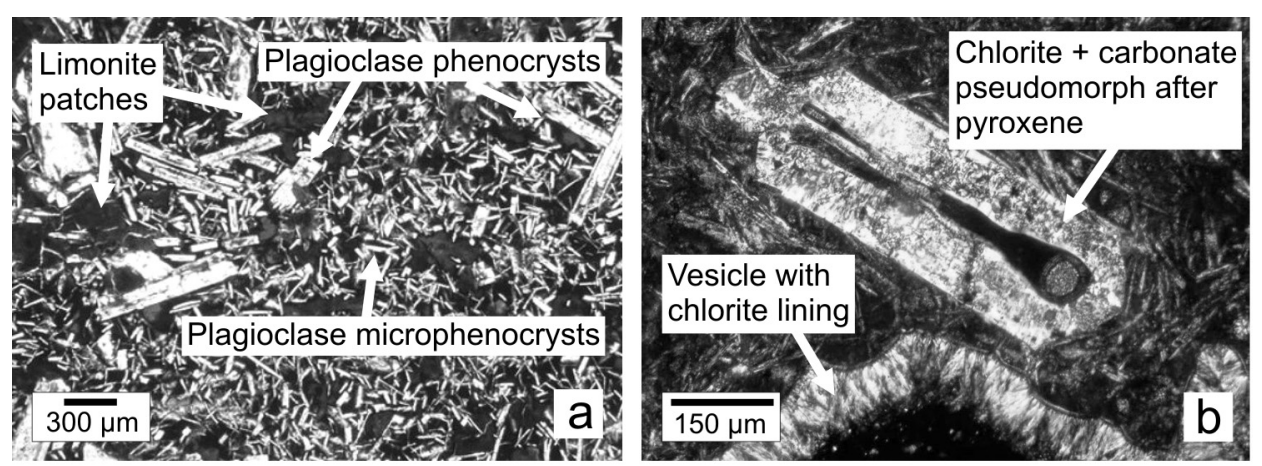

Fig. 4

a) Üllés-36, 1N) and b) Ruzsa-12, +N) Spherulitic texture and the main components of basalt
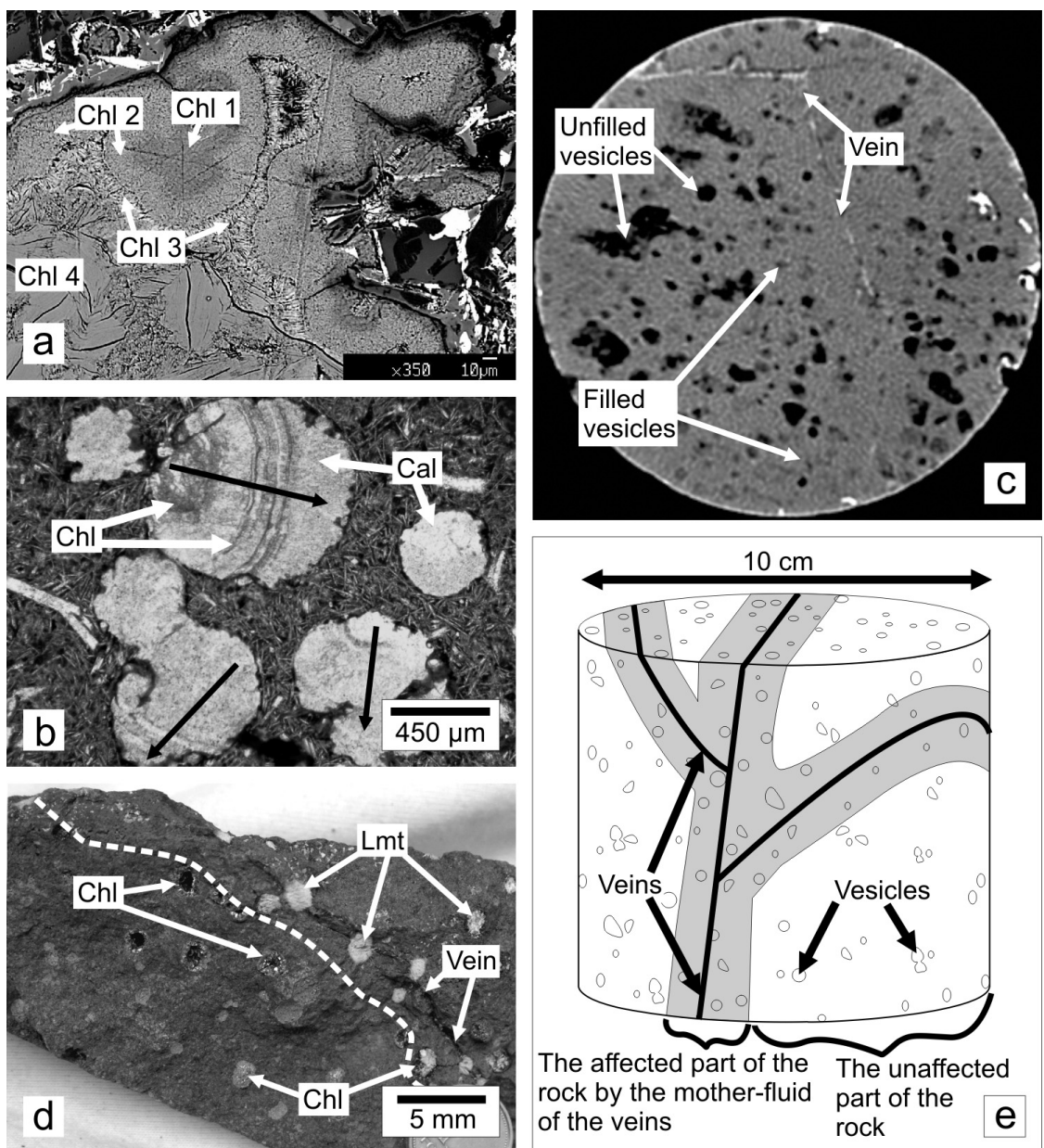

Central European Geology 52, 2009 
appears as brown patches in the matrix (Fig. 4a). The chloritized and carbonated clinopyroxene phenocrysts appear as pseudomorphs in most cases (Fig. $4 \mathrm{~b}$ ), but in some places fresh clinopyroxene crystals can also be found. In addition to the chloritization of mafic phenocrysts, chlorite is the principal cement phase in the vesicles (Figs $4 \mathrm{~b}$ and $5 \mathrm{a}$ ). It is extremely fine-grained, and appears as green to brown in thin section as the replacement mineral of the glassy matrix and mafic phenocrysts. Several samples contain fine-grained pyrite crystals scattered in the matrix or in vesicles followed by chlorite.

The lapilli and the lava rock samples are very rich in vesicles with mostly spherical or irregular shapes scattered in the rock without any preferred orientation (Fig. 2b). Away from the veins, most vesicles are filled partly or fully with chlorite, or with quartz and prehnite followed by chlorite crystals. In the vesicles, chlorite occurs with a different morphology and color. The fine-grained brownish-green type is followed by dark green grains, radial aggregates of small green needles and finally light green fans of fibers (Fig. 5a). In places vesicles are completely filled by calcite, containing chlorite zones (Fig. $5 b$ ). These zones have different orientations in the neighboring vesicles. The CT measurements show that the vesicles near the fractures are filled, but away from them the vesicles are usually empty (Fig. 5c). Along the veins, inside a zone a couple of centimeters wide, the vesicles are full of different fracture-filling minerals (Fig. 5c, d and e).

\section{Veins}

Based on their host rock, occurrence, vein microstructure and cement minerals, four distinct vein types can be distinguished in the studied cores using microscopy, SEM and Raman microspectroscopy (Table 2).

Type 1 veins could be identified only inside the lapilli of pyroclastic rock samples. The narrow veins (with a maximum aperture of $2 \mathrm{~mm}$ ) crosscut the lapilli, but the end at their edges (Fig. 6a). Euhedral K-feldspar crystals grow from the vein wall towards the center of the vein followed by idiomorphic quartz and albite crystals (Fig. 6b). The remnant volume was filled by laumontite and in places calcite (Fig. 6c). Based on the growth directions of the K-feldspar, quartz and albite crystals, the microstructure of the vein is syntaxial (Bons 2000; Oliver and Bons 2001) (Fig. 6d).

$\leftarrow$ Fig. 5

a) SEM image of the subsequent chlorite (Chl) phases (Üllés-77), b) Alternating precipitation of calcite (Cc) and chlorite (Chl); black arrows show the growth direction inside the vesicles (Üllés-43), c) CT image of a Üllés-36 core sample from 2,266 m: vesicles are filled by minerals near to the vein and are empty a little further away from it. The diameter of the core sample is $10 \mathrm{~cm}, \mathrm{~d}$ ) The same in the core sample from Üllés-77. Dashed line represents the border of the affected and unaffected zones. In the affected zone the vein-filling laumontite (Lmt) precipitated on chlorite (Chl) in the vesicles. In the unaffected zone the vesicles remained empty after an initial chlorite lining, e) Sketch shows that the rock away from the veins was not affected by the mother fluid of the fracture-filling minerals and is devoid of these minerals; near the veins the appearance of these minerals can be observed 
Table 2

Vein types

\begin{tabular}{|c|c|c|c|c|}
\hline Host rock & Type 1 & Type 2 & Type 3 & Type 4 \\
\hline $\begin{array}{c}\text { Occurrence in } \\
\text { wells of }\end{array}$ & Ruzsa-21, Üllés-61 & $\begin{array}{c}\text { bordány-2, Üllés- } \\
77\end{array}$ & $\begin{array}{c}\text { Ruzsa and Üllés } \\
\text { area (except for: } \\
\text { Üllés-61) }\end{array}$ & $\begin{array}{c}\text { Üllés-61, Üllés- } \\
\text { pyroclast }\end{array}$ \\
\hline $\begin{array}{c}\text { Vein } \\
\text { microstructure (in cuttings) }\end{array}$ & syntaxial & antitaxial & syntaxial (ataxial) & syntaxial \\
\hline $\begin{array}{c}\text { Cement } \\
\text { minerals }\end{array}$ & $\begin{array}{c}\text { K-feldspar, quartz, } \\
\text { albite, laumontite, } \\
\text { calcite }\end{array}$ & $\begin{array}{c}\text { Weathered } \\
\text { volcanic material, } \\
\text { calcite, } \\
\text { heulandite }\end{array}$ & $\begin{array}{c}\text { Prehnite } \\
\text { chlorite, laumontite, } \\
\text { thomsonite, } \\
\text { laumontite, } \\
\text { calcite }\end{array}$ & $\begin{array}{c}\text { Analcime mesolite, } \\
\text { analcime, } \\
\text { heulandite, stilbite }\end{array}$ \\
\hline
\end{tabular}
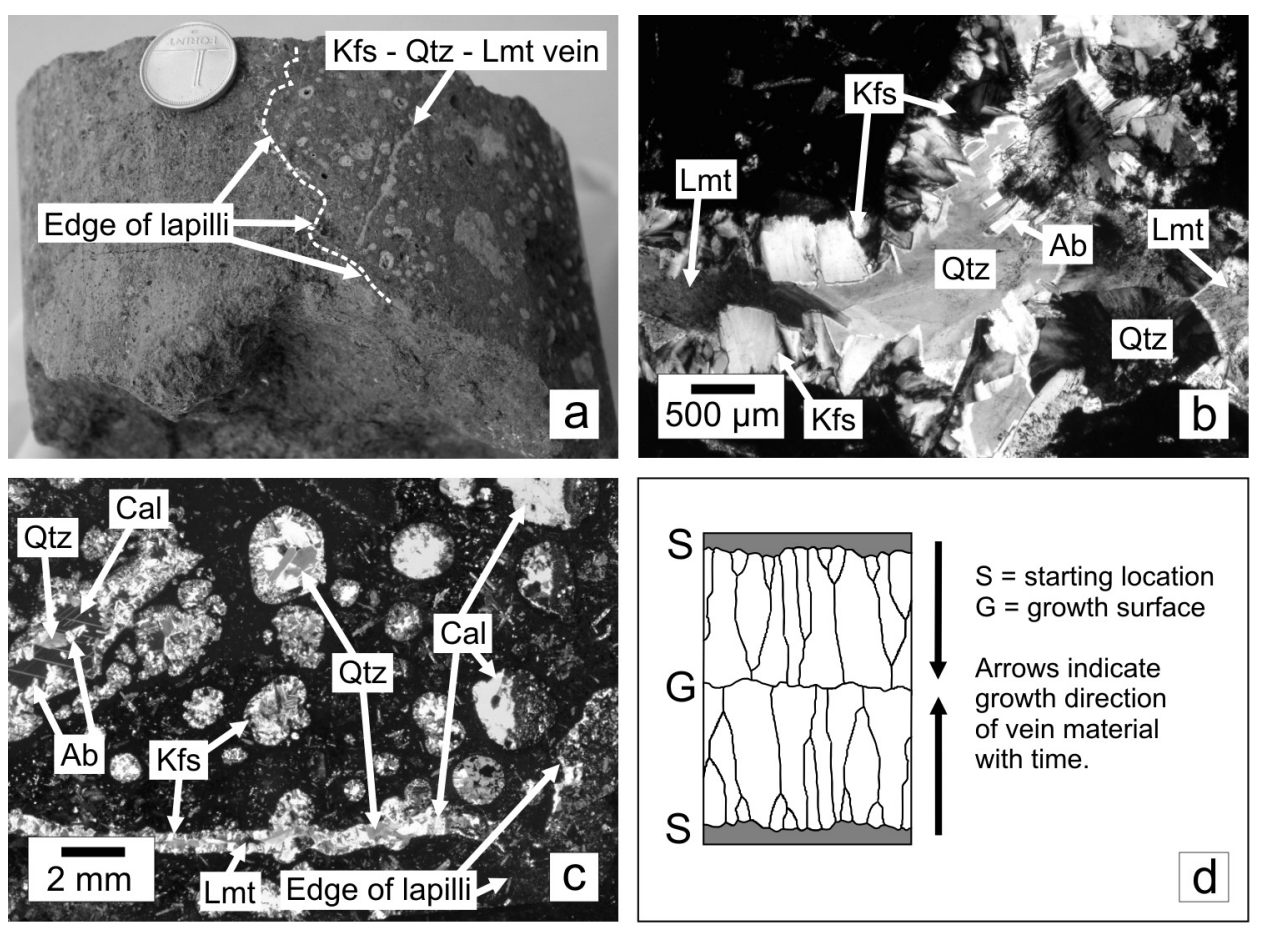

Fig. 6

Characteristics of vein Type 1. a) Macroscopic appearance of the vein in a lapillus from the Ruzsa-21 well, b) Microscopic appearance of the vein (Kfs-K-feldspar, Qtz-quartz, Ab-albite, Lmt-laumontite and Cc-calcite) (Ruzsa-21), c) Vein and vesicle-filling minerals in a lapillus (Ruzsa-21), d) Typical growth pattern of the syntaxial vein texture is indicated on the sketch modified after Oliver and Bons (2001) 
The rare, narrow (up to 3-6 $\mathrm{mm}$ ) veins of Type 2 occur exclusively in lava rock samples. They are subvertical with a dip of $70-90^{\circ}$. The central parts of the symmetrical veins are filled with altered volcanic material, while the vein walls are covered by calcite (Fig. 7a). Mostly, the opposite vein wall planes can be well fitted. In places, this altered material contains small grains from the wall rock and narrow calcite microveins, crosscutting the central filling. In the symmetric calcite filling of the main vein, the number of the calcite grains decreases away from the central part, and the faster growing "winner" crystals widen towards the vein walls at the expense of the "loser" grains (following the nomenclature of Bons 2001). Based on the crystallographically-controlled growth competition, the growth direction of the calcite crystals points from the central part of the vein towards the vein walls (Bons 2000, 2001; Oliver and Bons 2001) (Fig. 7a inset A). The shape of the calcite crystals is mostly elongated and blocky along the main vein, except for the stretched, deformed crystals in places (Fig. 7a inset B).
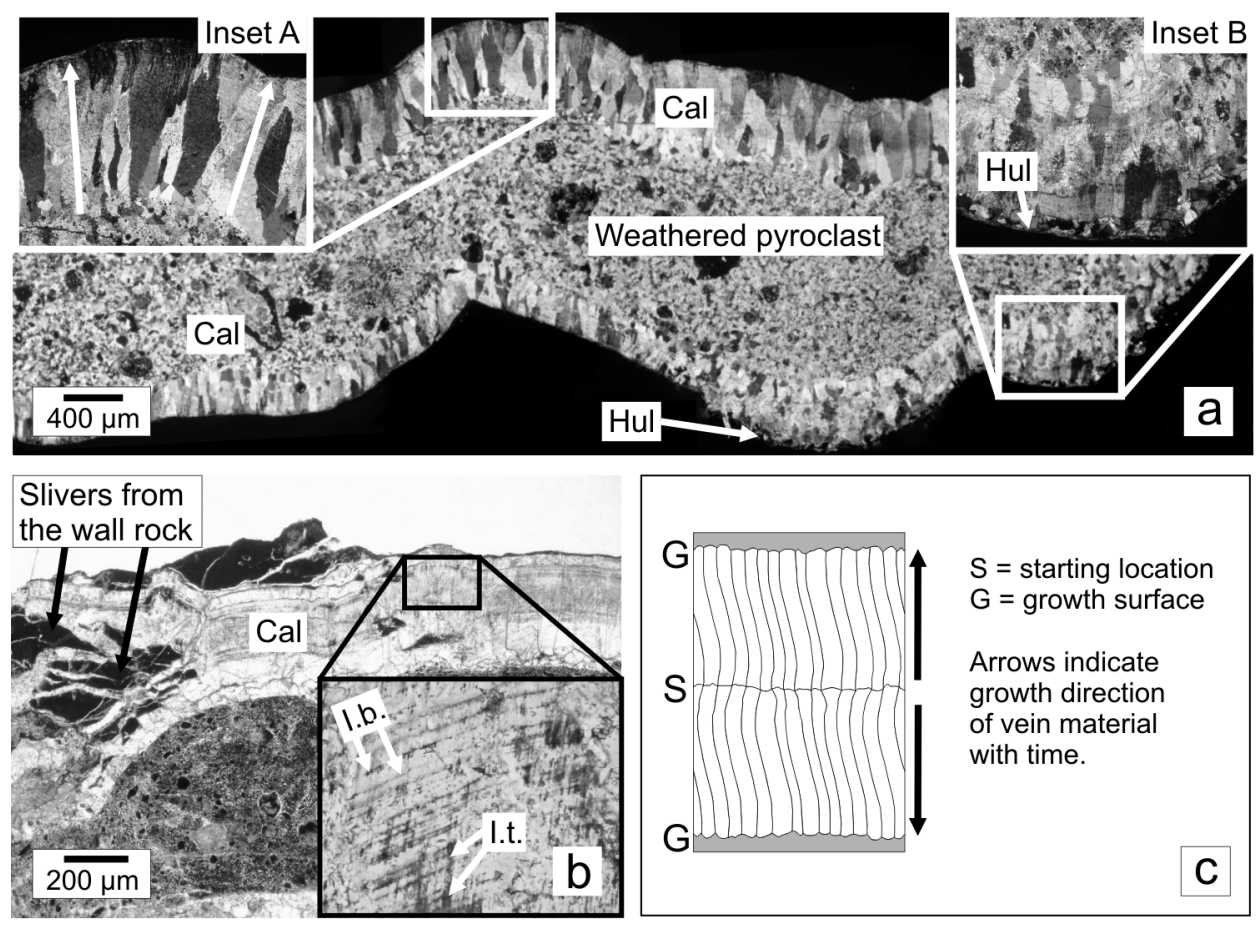

Fig. 7

Characteristics of vein Type 2. a) Antitaxial texture of the symmetric calcite (Cc) vein $(B o-2,+N)$. The crystals were widening towards the vein wall as they were growing, as presented in Inset A: the growth direction of the calcite crystals $(\mathrm{Cc})$ thus points to the wall rock. Inset B shows the local appearance of heulandite rim (Heu) with the stretched calcite crystals (Cc). b) The appearance of solid inclusion bands (I.b.) and trails (I.t.) in the calcite filling (Cc) indicates the function of the crack-seal mechanism during precipitation of the vein $(B o-2,1 N)$, c) Sketch of the typical growth pattern of an antitaxial vein (modified after Oliver and Bons 2001) 
Between the stretched calcite crystals and the vein wall (up to $50 \mathrm{~mm}$ ), a narrow asymmetric zeolite (heulandite) rim appears (Fig. 7a Inset B). The calcite crystals contain several solid inclusions parallel to the vein walls ("inclusion bands") and normal to them ("inclusion trails") (following the nomenclature of Bons 2000) as well as bigger slivers from the wall rock (Fig. $7 \mathrm{~b}$ ). These slivers can be well fit to each other and to the vein wall (Fig. $7 \mathrm{~b}$ ). The EDS spectra show high $\mathrm{Fe}, \mathrm{Mg}, \mathrm{Ca}$, $\mathrm{Al}$ and $\mathrm{Si}$ contents in the solid inclusions, suggesting that they originate from the basaltic wall rock (Fig. 7c). Based on this behavior the microstructure of the vein is antitaxial (Fig. 7c).

The dense network of Type 3 veins with a maximum aperture of 2 centimeters appears in most samples in the Üllés and Ruzsa areas in both basaltic and pyroclastic rock cores (Fig. 8a). In a few cases they clearly crosscut Type 2 veins. In places within both the Üllés and the Ruzsa areas, grayish-blue prehnite crystals occur directly on the vein wall (Fig. 8d). Prehnite nodules exhibit a corerim texture defined by fluid inclusions, suggesting a two-stage growth. Based on EDS analysis the crystals are chemically homogeneous. The rims of the prehnite crystals in places contain laumontite inclusions, suggesting that laumontite crystallization started during the last growth stage of prehnite (Fig. 10e). Type 3 veins are mostly filled by laumontite and calcite (Fig. 8a and b). Away from the vein wall, the fibrous laumontite crystals usually contain needle-shaped inclusions identified as thomsonite by Raman spectroscopy (Fig. 8c). The thomsonite inclusion-bearing laumontite phase was followed by pure laumontite fibers and small, blocky calcite crystals growing toward the centers of the veins (Fig. 8e). The late laumontite and calcite cements contain green chlorite crystals as solid inclusions (Fig. 8d). Many calcite crystals enclose fluid inclusion bands subparallel to the vein wall (Fig. 10f). Some of the calcite crystals are twinned, but the thickness of the twins and the direction of twining are different in the crystals. Based on the growth competition pattern, Type 3 veins show syntaxial vein microstructure (Bons 2000, 2001; Oliver and Bons 2001) (Fig. 8e). In some samples the sequence of the fracture-filling minerals is not obvious because calcite microveins crosscut the laumontite cement and the host rock, parallel to the laumontite-calcite vein. These microveins and the inclusion bands of the calcite crystals suggest that the veins opened in several steps in different places (ataxial vein). In places, striae can be observed on the vein wall under the laumontite fibers (Fig. 8f).

Type 4 veins (with a maximum aperture of 2 centimeters) occur only in the well-cemented cores of the Üllés-61 well (Fig. 9a). The angular grains of the host rock show a brecciated structure, and debris of vitrophyric-rimmed lapilli occurs among these rock fragments (Fig. 9a). The vein-filling minerals are mesolite, analcime, heulandite and stilbite (Fig. 9b). The tiny needles of mesolite appear as solid inclusions within the main vein-filling analcime and heulandite crystals. Based on optical observations and Raman spectroscopy on cuttings, we assume the presence of the same vein type in the Üllés-65/A well. 

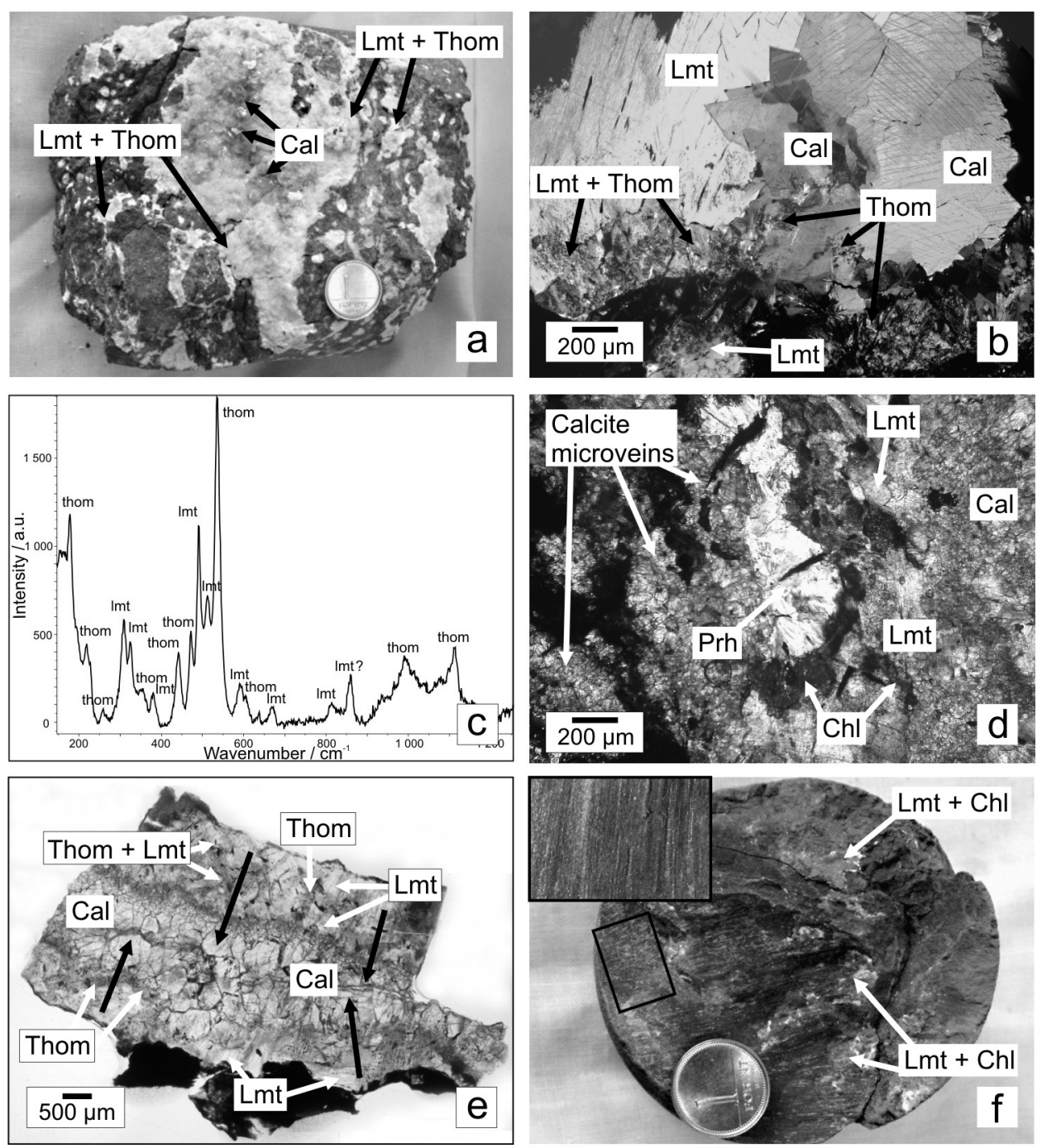

Fig. 8

Characteristics of vein Type 3. a) Macroscopic appearance of this vein type filled with laumontite (Lmt), thomsonite (Thom) and calcite (Cc) (Ü-36), b) Microscopic appearance of the vein. Following early precipitation of laumontite and thomsonite there is a later laumontite phase without thomsonite $($ Ü-36, +N), c) Raman spectrum of thomsonite (Ü-36), d) Prehnite (Prh) appearance and chlorite (Chl) inclusions in laumontite in vein Type 2 . The calcite microveins in the rock point to several opening events showing ataxial vein microstructure $(\mathrm{Ru}-13,+\mathrm{N})$, e) The growth directions of the crystals (black arrows) point to the central part of the vein, showing its syntaxial microstructure (Ru-13, 1N), f) On the fracture wall striae can be observed at places with laumontite patches on it $(\mathrm{Ru}-12)$ 

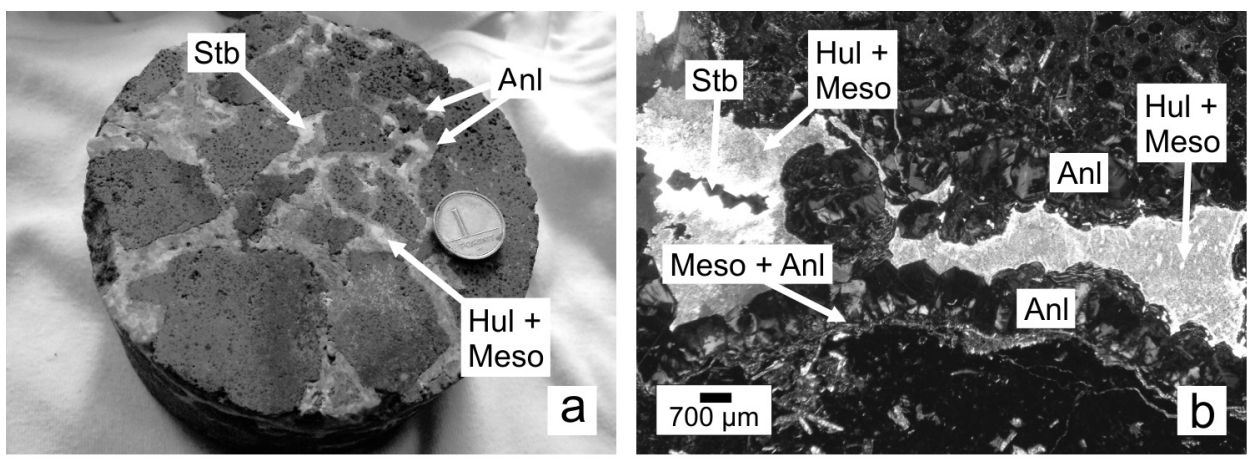

Fig. 9

Textural characteristics of vein Type 4. a) Macroscopic appearance of vein Type 4, where the wellcemented fragments are in a brecciated structure. The fragments with dark rims could be the parts of a lapillus (Ü-61), b) Syntaxial veins are filled with analcime (Ana), mesolite (Meso), heulandite (Hul) and stilbite (Stb) (Ü-61, +N)

\section{Chlorite thermometry}

Chlorite is the main vesicle-filling mineral, but chlorite crystals appear in Type 3 veins as well, trapped in laumontite and calcite crystals. Four subsequent chlorite types can be distinguished in both vesicles and veins by their color and morphology (Fig. 5a). Microprobe measurements show different compositions for all of these types (Table 3). The $\mathrm{Al}_{2} \mathrm{O}_{3}$ and $\mathrm{FeO}$ contents increase continuously from the cores of the aggregates ( $\mathrm{Chl} 1$ ) and become constant in the light green crystals of the outermost generation (Chl 4) (Fig. 5a). Based on mineral chemistry, the formation temperature can be established with several chlorite solid-solution geothermometers. The method of Cathelineau (1988) is based on the empirical approach that AlIV in the chlorite structure is correlated with the precipitation temperature. Kranidiotis (1987) modified the approach of Cathelineau and Nieva (1985) with a correction for the changes of $\mathrm{Fe} /(\mathrm{Fe}+\mathrm{Mg})$. Jovett (1991) also modified the original geothermometer of Cathelineau and Nieva (1985), taking into account the variation of $\mathrm{Fe} /(\mathrm{Fe}+\mathrm{Mg})$ in chlorite.

The estimated formation temperatures represent a warming trend from Chl 1 to $\mathrm{Chl} 3$ without any significant change in the last phase (Chl 4) compared to the third type (Chl 3). Based on the formula of Cathelineau (1988), the temperature increased from about $140{ }^{\circ} \mathrm{C}$ to $205^{\circ} \mathrm{C}$, from 185 to $220^{\circ} \mathrm{C}$ using Kranidiotis (1987) and from 145 to $210{ }^{\circ} \mathrm{C}$ based on Jovett (1991), along the precipitation path of subsequent chlorite generations. The formulae and calculated temperatures are listed in Table 3. 
Table 3

Chlorite composition data and thermometric calculations

\begin{tabular}{|c|c|c|c|c|}
\hline Composition* & $\mathrm{Chl} 1$ & Chl 2 & $\mathrm{Chl} 3$ & Chl 4 \\
\hline $\mathrm{SiO}_{2}$ & 32.247 & 32.002 & 29.231 & 30.603 \\
\hline $\mathrm{Al}_{2} \mathrm{O}_{3}$ & 13.442 & 14.359 & 13.95 & 13.79 \\
\hline $\mathrm{FeO}$ & 22.737 & 23.033 & 26.147 & 23.313 \\
\hline $\mathrm{MgO}$ & 14.551 & 15.576 & 12.757 & 19.332 \\
\hline $\mathrm{Na}_{2} \mathrm{O}$ & 0.483 & 0.267 & 0.246 & 0.030 \\
\hline $\mathrm{MnO}$ & 0.257 & 0.314 & 0.341 & 0.294 \\
\hline $\mathrm{CaO}$ & 1.583 & 0.699 & 0.636 & 0.280 \\
\hline $\mathrm{K}_{2} \mathrm{O}$ & 0.232 & 0.206 & 0.154 & 0.023 \\
\hline $\mathrm{TiO}_{2}$ & 0.055 & 0 & 0.146 & 0 \\
\hline Total & 85.587 & 85.456 & 83.608 & 87.665 \\
\hline Al total & 3.371 & 3.554 & 3.665 & 3.381 \\
\hline $\mathrm{Al}^{\mathrm{IV}}$ & 1.222 & 1.350 & 1.536 & 1.642 \\
\hline $\mathrm{Al}^{\mathrm{IV}}$ half formula & 0.611 & 0.675 & 0.768 & 0.821 \\
\hline $\mathrm{Al}_{c}^{\mathrm{IV}}$ Kranidiotis $^{* * *}$ & 1.548 & 1.667 & 1.910 & 1.924 \\
\hline $\mathrm{Al}_{\mathrm{C}}^{\mathrm{IV}}$ Jovett $^{* * * *}$ & 0.657 & 0.720 & 0.821 & 0.861 \\
\hline \multirow[t]{2}{*}{$\mathrm{Fe} /(\mathrm{Fe}+\mathrm{Mg})$} & 0.467 & 0.453 & 0.535 & 0.404 \\
\hline & \multicolumn{4}{|c|}{ Calculated temperatures $\left({ }^{\circ} \mathrm{C}\right)$} \\
\hline Cathelineau $(1988)^{\star *}$ & 135 & 155 & 185 & 202 \\
\hline Kranidiotis $(1987)^{* * *}$ & 182 & 195 & 221 & 222 \\
\hline Jovett $(1991)^{\star * * *}$ & 141 & 161 & 193 & 206 \\
\hline
\end{tabular}

* Representative compositions from the subsequent chlorites (Chl 1-4)

$* * \mathrm{~T}\left({ }^{\circ} \mathrm{C}\right)=-61.92+321.98^{*} \mathrm{Al}(\mathrm{IV})$

$* * * \mathrm{~T}\left({ }^{\circ} \mathrm{C}\right)=106^{*} \mathrm{AlCIV}+18$, where AlCIV $=\mathrm{AlIV}+0.7^{*}[\mathrm{Fe} /(\mathrm{Fe}+\mathrm{Mg})]$

$* * * * \mathrm{~T}\left({ }^{\circ} \mathrm{C}\right)=319^{*} \mathrm{AlCIV}-69$, where AlCIV $=\mathrm{AlIV}+0.1[\mathrm{Fe} /(\mathrm{Fe}+\mathrm{Mg})]$

\section{Fluid inclusion petrography and microthermometry}

Fluid inclusion microthermometry was performed on fracture-filling minerals of rock samples with a well-defined position in the mineral sequence (Table 4).

In Type 1 veins, K-feldspar, quartz and calcite crystals contain fluid inclusion assemblages those are suitable for microthermometry (Fig. 10a, b and c). The Kfeldspar crystals contain low quantities of irregularly-shaped, measurable fluid inclusions. The primary, two-phase $(\mathrm{L}+\mathrm{V})$ aqueous inclusions appear isolated in the small crystals (Fig. 10a) and are homogenized into the liquid phase between 142 and $158{ }^{\circ} \mathrm{C}$. The final ice melting temperature of the inclusions is $-0.3{ }^{\circ} \mathrm{C}$, 
314 B. Szabó et al.

Table 4

Summary of fluid inclusion and microthermometric data

\begin{tabular}{|c|c|c|c|c|c|c|}
\hline $\begin{array}{c}\text { Vein } \\
\text { type }\end{array}$ & $\begin{array}{c}\text { Host } \\
\text { mineral }\end{array}$ & $\begin{array}{c}\text { Inclusion } \\
\text { type }\end{array}$ & $\begin{array}{c}\boldsymbol{T}_{\mathrm{h}} \\
\left({ }^{\circ} \mathrm{C}\right)\end{array}$ & $\begin{array}{c}\boldsymbol{T}_{\mathrm{m}}(\mathrm{Ice}) \\
\text { range }\left({ }^{\circ} \mathrm{C}\right)\end{array}$ & $\begin{array}{c}\text { Salinity } \\
\text { (mass\% } \\
\text { NaCleq) }\end{array}$ & $\mathbf{n}$ \\
\hline Type 1 & K-feldspar & $\mathrm{P}(\mathrm{L}+\mathrm{V})$ & $142-158$ & $(-0.2)-(-0.3)$ & $0.35-0.53$ & 12 \\
\cline { 2 - 7 } & Quartz & $\mathrm{P}(\mathrm{L}+\mathrm{V} \pm \mathrm{S})$ & $138-152$ & $(-0.1)-(-0.2)$ & $0.18-0.35$ & 18 \\
\cline { 2 - 7 } & Quartz & $\mathrm{S}(\mathrm{L}+\mathrm{V} \pm \mathrm{S})$ & $135-151$ & $(-0.1)-(-0.2)$ & $0.18-0.35$ & 10 \\
\cline { 2 - 7 } & Calcite & $\mathrm{P}(\mathrm{L}+\mathrm{V})$ & $137-154$ & $(-0.2)-(-0.4)$ & $0.35-0.71$ & 17 \\
\hline Type 3 & Prehnite & $\mathrm{P}(\mathrm{L}+\mathrm{V})$ & $135-180$ & $(-0.3)-(-0.5)$ & $0.53-0.88$ & 28 \\
\cline { 2 - 7 } & Calcite & $\mathrm{S}(\mathrm{L}+\mathrm{V})$ & $139-150$ & n. d. & n. d. & 5 \\
\hline
\end{tabular}
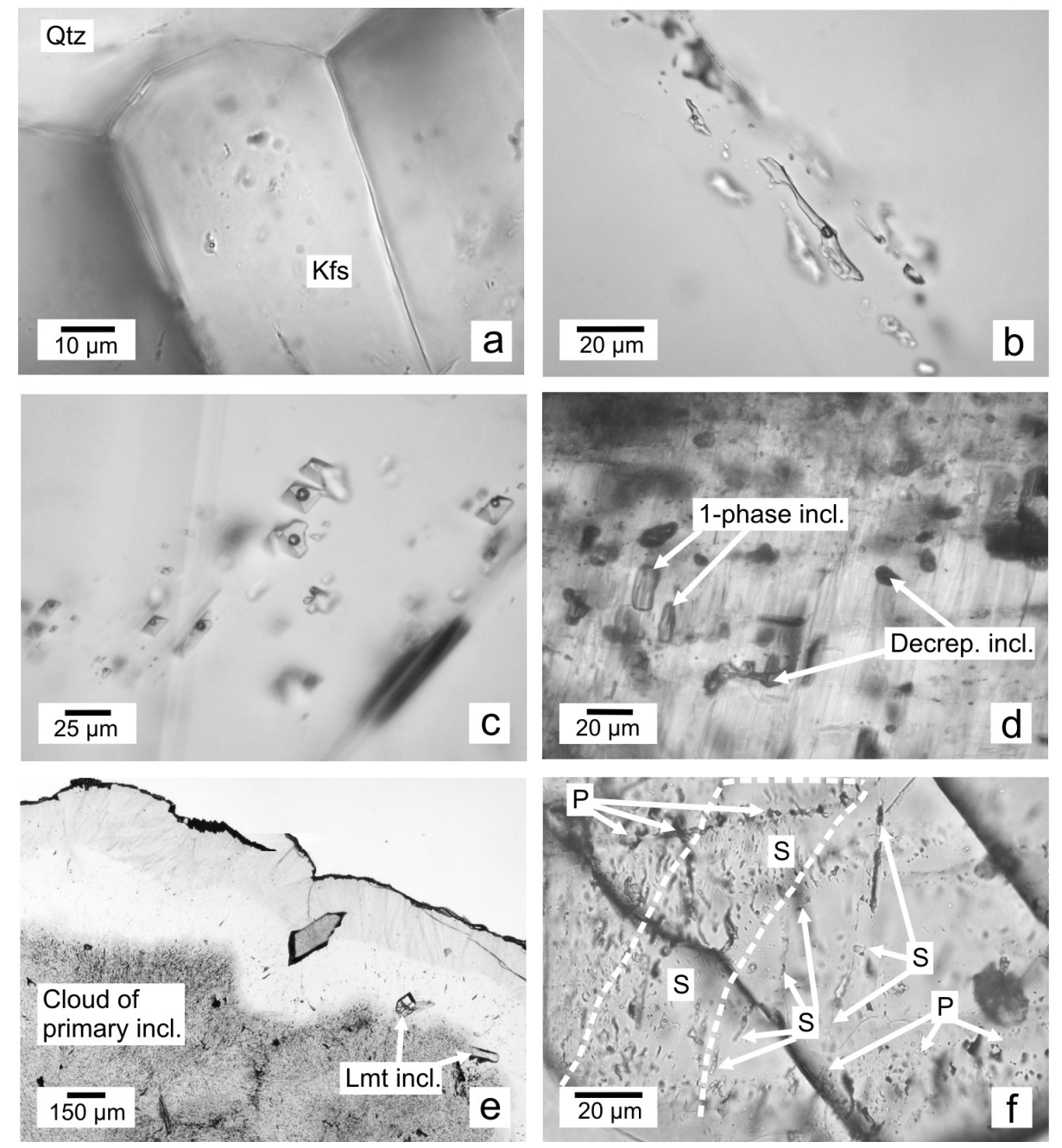

Central European Geology 52, 2009 
suggesting a maximum salinity of 0.53 mass $\%$ NaCleq. The two-phase $(\mathrm{L}+\mathrm{V})$ aqueous fluid inclusions in the quartz crystals compose extended "clouds" within the crystals (primary fluid inclusions) and occur along trails ending at the edges of the crystals (secondary fluid inclusions). These trails never continue in the neighbouring feldspar or calcite grains. The aqueous inclusions contain accidentally trapped solid particles in places (Fig. 10b). The small sheets of translucent amorphous crystals have a light green color under one Nikol. The homogenization temperatures $\left(\mathrm{T}_{\mathrm{h}}\right)$ are between 138 and $152{ }^{\circ} \mathrm{C}$ in the case of primary aqueous inclusions, and between 135 and $151^{\circ} \mathrm{C}$ in the case of secondary aqueous inclusions. The $\mathrm{T}_{\mathrm{m}}$ (Ice) of the inclusions is $-0.2^{\circ} \mathrm{C}$, suggesting a very low salinity ( 0.35 mass\% NaCleq). The negative crystal-shaped, two-phase aqueous inclusions occur in small groups in the calcite crystals (Fig. 10c). These primary fluid inclusions homogenize into the liquid phase between 137 and $154^{\circ} \mathrm{C}$. The $\mathrm{T}_{\mathrm{m}}$ (Ice) of the inclusions is $-0.4{ }^{\circ} \mathrm{C}$, suggesting the highest salinity in this vein type (0.71 mass\% NaCleq). On the basis of Raman microspectroscopy the twophased inclusions in the K-feldspar, quartz and calcite crystals, contain methane in the vapor phase at room temperature.

In Type 3 veins, several fluid inclusion assemblages were identified in the prehnite and calcite crystals. There is no fluid inclusion suitable for microthermometry in laumontite, because the single-phase (L) inclusions usually decrepitate at room temperature, presumably due to the "open-structure" of the crystals (Juhász et al. 2002) (Fig. 10d). The dark cores of the prehnite crystals are the result of the tiny primary two-phase aqueous fluid inclusions appearing in large quantities (Fig. 10e). The inner zone is crosscut by trails of secondary twophase aqueous fluid inclusions. The primary aqueous inclusions homogenize into the liquid phase between 130 and $181{ }^{\circ} \mathrm{C}$, while the temperature of final ice melting is $-0.5{ }^{\circ} \mathrm{C}$, suggesting a salinity of 0.88 mass $\%$ NaCleq. The primary inclusions contain methane in the vapor phase at room temperature, identified by Raman microspectroscopy. Some less twinned calcite crystals contain onephase $(\mathrm{L})$ and two-phase $(\mathrm{L}+\mathrm{V})$ aqueous fluid inclusion bands parallel to the vein wall (Fig. 10f), which can be regarded as primary inclusions in the case of ataxial vein microstructure. These inclusions are too small $(<5 \mu \mathrm{m})$ for microthermometric measurements. The parallel bands are crosscut by two-phase $(\mathrm{L}+\mathrm{V})$, aqueous inclusion trails (secondary inclusions) (Fig. 10f), and homogenize between 135 and $150{ }^{\circ} \mathrm{C}$ into liquid phase. Based on Raman microspectroscopy, the two-phase aqueous inclusions of calcite contain no methane.

$\leftarrow$ Fig. 10

Fluid inclusions in the fracture-filling minerals. a) Primary, irregularly-shaped aqueous inclusion in Kfeldspar (Type 1) (Ru-21, 1N), b) Primary, three-phase aqueous inclusions in quartz (Type 1) (Ru-21, $1 \mathrm{~N})$, c) Primary, negative crystal-shaped aqueous inclusions in calcite (Type 1) (Ru-21, 1N), d) Onephase and decrepitated inclusions in laumontite (Type 3) (Ru-13, 1N), e) Crowd of primary twophased aqueous inclusions in the inner zone of a prehnite crystal. Laumontite (Lmt) inclusions in the outer zone are also observable (Type 3) (Ü-36,1N), f) Bands of primary $(\mathrm{P})$ one-phase inclusions and trails of secondary (S) two-phase inclusions in a calcite crystal (Type 3) (Ru-13, 1N) 
Microthermometric measurements in analcime and heulandite crystals of Type 4 veins are outside of the scope of the present study.

\section{Discussion and conclusion}

Basic characteristics of the host rock

Most core samples representing the KBF in the area of Üllés-Ruzsa-Bordány (Fig. 1) are pyroclastic rocks and to a lesser extent lava rocks (Fig. 2a and b). In several wells both lithologies occur. The lava rock samples and the lapilli of the pyroclastics are full of vesicles and amigdaloids (Fig. 2a and b), suggesting the high fluid content of the magma. The mostly spherical vesicles and the variolitic, spherulitic texture of the rock with the predominantly microsize of the plagioclase phenocrysts (Fig. 4a) suggest rapid cooling. Amphibole and pyroxene crystals appear as chlorite and carbonate pseudomorphs, and chlorite appears diffuse in the matrix and as a vesicle filling (Fig. 4b). The intensive chloritization and carbonatization provide evidence for extensive metasomatism of the rock. The formation of such a chlorite-rich assemblage supposes a high water/rock ratio (>10; Humphris and Thompson 1978).

Based on all of these textural features, as well as the presence of intercalated marl layers and marl inclusions in the volcanic succession, a subaqueous character of the volcanism is suggested. Based on the available paleontological data (Balázs and Nusszer 1987), we conclude that there was a changing water depth, similarly to the area of Battonya and Magyarbánhegyes, where pyroclasts of KBF are intercalated in marl layers of EMF (Magyar et al. 2004).

Based on macroscopic observations and CT measurements, most vesicles are just partly filled away from the veins (Fig. $5 \mathrm{c}$, d and e). In most cases only chlorite was precipitated in these vesicles (Fig. 5a); while in places prehnite and quartz predate chlorite. The calcite-filled vesicles with chlorite inclusion zones suggest that carbonate crystallization was synchronous with chloritization (Fig. 5b). Zeolites crystallized in a zone just a couple of centimeters wide along the veins. They presumably precipitated in connection with vein cementation processes in a fracture-controlled system.

\section{Evaluation of vein textures}

Based on their occurrence, vein texture and mineralogy, four distinct vein types can be distinguished (Table 2), among which Type 3 is the most extensively developed variety in the whole area of Üllés-Ruzsa-Bordány.

Based on macroscopic observations about the crosscutting relationships of different vein types, the temporal sequence of Types 2 and 3 can be clarified. Crosscutting Types 1 and 2 veins have not been found, so there is no direct evidence concerning their sequence in the rock. As Type 1 veins do not continue in the weathered volcanic material among the lapilli (Figs 6a and c), they 
presumably formed before the consolidation of the pyroclastic sediment. The altered volcanic material is the first vein-filling substance in Type 2 veins of the massive basalt (Fig. 7a). Although there are no textural data about their age relationships, both Type 1 and Type 2 veins formed prior to significant diagenesis of the pyroclastic material, so they must be about the same age.

Under the microscope Type 1 veins exhibit a syntaxial texture, because the growth direction of the K-feldspar and quartz crystals points from the fracture wall to the center of the vein (Fig. 6b) (Bons 2000). In the case of this texture type, the transport mechanism of the host-fluid was presumably advection (Bons 2000; Oliver and Bons 2001), so a fracture-controlled fluid flow can be assumed at the time of K-feldspar and quartz cementation in Type 1. Based on microthermometric measurements K-feldspar and quartz crystals precipitated from source fluids with low salinity (0.53 mass\% NaCleq in the case of K-feldspar; 0.35 mass $\%$ NaCleq in the case of quartz), while calcite crystallization happened from a fluid with a somewhat higher salinity ( 0.71 mass\% NaCleq) (Table 4$)$.

The well-fitted vein wall planes and the massive host rock suggest that weathered volcanic material with tiny rock grains did not arise from in situ weathering, but was transported there by advection after fracturing. The calcite crystals of this vein type nevertheless show a well-developed antitaxial texture (Fig. 7a) (Bons 2000, 2001; Bons and Montenari 2005). This texture is interpreted by several authors (Durney and Ramsay 1973; Fisher and Barntley 1992; Bons and Jessel 1997) as a result of precipitation from fluid diffusing through the wall rock. Hilgers et al. (2001) disagree with this explanation because their digital simulations on vein formation show that the antitaxial texture of fibrous crystals could be the result of advective transport. In Type 2 veins, the length/width ratio of calcite crystals is less than 10 , so the shapes of the crystals are elongate blocky rather than fibrous. The elongate blocky microstructure indicates that crystallization occurred in fluid-filled cracks. The "bands" and "trails" of solid inclusions originated from the wall rock are evidence for a crack-seal mechanism, i.e. several alternating microscale opening and healing events had to happen in the veins (Fig. 7b) (Ramsay and Huber 1987). This mechanism was modeled by Hilgers et al. (2001), using the digital approach of Bons (2001). The model suggests that if veins exhibit textural features of both crack-seal mechanism and growth competition, the size of each incremental opening episode had to be smaller than about $10 \mu \mathrm{m}$. The presence of solid inclusions and slivers from the wall rock in calcite are evidence against advection as a main procedure and make diffusion in the rock matrix more likely, because in the case of advection, water would carry away these small fragments (Fig. 7b). The local appearance of stretched calcite crystals and the narrow heulandite rim makes a later re-opening event probable in the Type 2 veins (Fig. 7a inset B).

The texture of Type 3 is syntaxial (Fig. 8e), pointing to an advection event at the time of cementation. In the case of Type 3 veins advection in open fractures is supported by the extensive appearance of laumontite crystals. Their shape and 
orientation suggest growth in suddenly opened fractures (Juhász et al. 2002). The latest calcite microveins (Fig. 8d) and the parallel fluid inclusion bands in calcite crystals (Fig. 10f) suggest an ataxial texture (Bons 2000). The vein opened in this case in several subsequent steps, and the precipitation of calcite was not fracturecontrolled. The ataxial texture implies diffusion as the main transport mechanism during precipitation of the last calcite phase. The dominant Type 3 veins also exhibit a dense fracture network in pyroclastic and lava rock samples (Fig. 8a). The veins of the pyroclastic core samples crosscut the lapilli and the matrix, suggesting brittle deformation of the rock after compaction of the pyroclastic strata. Striae can be observed rarely on the vein walls, suggesting motion of blocks along the opened fractures before laumontite precipitation (Fig. 8f).

\section{Thermal evolution}

On the basis of the sequence of fracture-filling minerals (Table 2), the P-T stability of the subsequent minerals can be calculated by the WinDomino modeling system using the thermodynamic database of Holland and Powell (1998). These results could be compared to and completed by the estimations of Liou et al. (1991) for the P-T stability fields of different zeolites, and by temperature data from fluid inclusion microthermometric measurements as well as borehole temperature measurements (Jorgensen 2006) (Table 5).

The sequence of zeolites could be used as an indicator of changing paleotemperature, as was reported from different volcanic provinces (Coombs et al. 1959; Neuhoff et al. 1997; Jorgensen 2006). Jorgensen (2006) shows that the regional zeolite distribution pattern reflects primarily variations in the maximum depth of burial of the basalt rather than differences in heat flow. It is possible to use a reference area with different heat flow values to compare the measured temperatures with our temperature calculations. In order to use zeolites as paleotemperature indicators it must be established that the formation of these minerals is nearly independent of pressure, provided that the pressure is not extremely high and the temperature is below the critical temperature of water $\left(374{ }^{\circ} \mathrm{C}\right)$. On the other hand the appearance of diverse zeolite phases is not independent of the chemical composition of the rock itself. Barth-Wirsching and Höller (1989) confirm that in order to compare zeolite zonation patterns, choosing a reference area with similar chemical compositions is crucial. The formation of zeolite zones could be associated with geothermal areas or could be the result of a burial diagenetic alteration of the basaltic rock. The burial diagenetic type of zeolite zonation has been described by Hay (1978), who distinguished four subsequent zones. The first zone (altered glass zone) is characterized by the absence of zeolites (1) and is followed downward by the clinoptilolite (2), analcime and heulandite (3) and laumontite and albite (4) zones. Iijima (1988) defined four zones in marine environments. The burial diagenetic type of zeolite zonation in the case of the sodic reaction series is characterized by 
Table 5

Summary of temperature calculations

\begin{tabular}{|c|c|c|c|c|c|}
\hline $\begin{array}{l}\text { Vein } \\
\text { types }\end{array}$ & $\begin{array}{l}\text { Cement } \\
\text { minerals }\end{array}$ & $\begin{array}{c}\text { Microthermom. } \\
T\left({ }^{\circ} \mathrm{C}\right)\end{array}$ & $\begin{array}{c}\text { DOMINO } \\
T\left({ }^{\circ} \mathrm{C}\right)\end{array}$ & $\begin{array}{c}\text { Liou (1991) } \\
T\left({ }^{\circ} \mathrm{C}\right)\end{array}$ & $\begin{array}{c}\text { Borehole } \\
T\left({ }^{\circ} \mathrm{C}\right)^{*}\end{array}$ \\
\hline \multirow{5}{*}{ Type 1} & \multirow{3}{*}{$\begin{array}{c}\text { K-feldspar } \\
\text { Quartz } \\
\text { Albite }\end{array}$} & $147 \pm 4$ & ** & & \\
\hline & & $145 \pm 7$ & & & \\
\hline & & & & $190<$ & \\
\hline & \multirow{2}{*}{$\begin{array}{c}\text { Laumontite } \\
\text { Calcite }\end{array}$} & & $100-225$ & $150-250$ & $\begin{array}{r}190-230 \\
(100-300) \\
\end{array}$ \\
\hline & & $144 \pm 7$ & & & \\
\hline \multirow{3}{*}{ Type 2} & \multirow{3}{*}{$\begin{array}{c}\text { Weathered } \\
\text { volcanic material } \\
\text { Calcite } \\
\text { Heulandite }\end{array}$} & & & & \\
\hline & & & & & \\
\hline & & & $140-190$ & $140-170$ & $110-130$ \\
\hline \multirow{5}{*}{ Type 3} & Prehnite & $160 \pm 20$ & $190-250$ & $200-380$ & $200<$ \\
\hline & Laumontite & & $100-225$ & $150-250$ & $\begin{array}{c}190-230 \\
(100-300)\end{array}$ \\
\hline & Thomsonite & & & & $\begin{array}{c}50-70 \\
(50-100)\end{array}$ \\
\hline & \multirow{2}{*}{$\begin{array}{c}\text { Laumontite } \\
\text { Calcite } \\
\end{array}$} & & $100-225$ & $150-250$ & $\begin{array}{c}190-230 \\
(100-300)\end{array}$ \\
\hline & & $135 \pm 5$ & & & \\
\hline
\end{tabular}

* from Jorgensen (2006)

Measured borehole temperature in the zone of the given zeolite.

In brackets the temperature of the given zeolite occurence throughout other zeolite zones as well.

** No data in the gray cells

the absence of zeolites (1) and followed by zones of clinoptilolite and mordenite (2), analcime (3), and in the deepest zone albite (4). In the calcic zeolite series, heulandite ( $3 \mathrm{a})$ and laumontite ( $3 \mathrm{~b}$ and $4 \mathrm{a}$ ) zones appear. The geothermal zeolite zones observed in the Faeroe Islands (Jorgensen 2006), in Iceland (Walker 1960), and in East Greenland (Neuhoff et al. 1997) are the following: thomsonitechabazite (1), analcime (2), mesolite-scolecite (3), heulandite-stilbite (4), and laumontite (5) from the surface down to greater depths and higher temperatures.

When applying P-T estimation approaches for the first three vein generations of the study area we obtain the following results. In Type 1 veins microthermometry indicates that the minimum temperatures of formation were between $142-155^{\circ} \mathrm{C}$ for K-feldspar, $138-152^{\circ} \mathrm{C}$ for quartz and between $137-154{ }^{\circ} \mathrm{C}$ for calcite. These homogenization temperatures $\left(\mathrm{T}_{h}\right)$ are very close to the true trapping temperatures ( $\left.\mathrm{T}_{\text {trap }}\right)$ in these cases, which is the formation temperature 
of the mineral phases (Schubert et al. 2007). If the liquid phases of these methanebearing aqueous inclusions are saturated with methane-rich vapor upon inclusion entrapment, then $\mathrm{T}_{\mathrm{h}}=\mathrm{T}_{\text {trap }}$ (Schubert et al. 2007). If the liquid phase is undersaturated with respect to methane, then $\mathrm{T}_{\mathrm{h}}<\mathrm{T}_{\text {trap}}$, but for a typical oilreservoir setting and degree of undersaturation like this case, the difference between $\mathrm{T}_{\mathrm{h}}$ and $\mathrm{T}_{\text {trap }}$ is minor $\left(<10^{\circ} \mathrm{C}\right.$; Schubert et al. 2007). The main fracturefilling mineral of Type 2 is calcite, which has an extremely wide stability zone in P-T space. As there are no fluid inclusions available for microthermometry in this calcite phase, the conditions of calcite precipitation cannot be estimated. Heulandite appears after a later microscale re-opening of Type 2. It is stable at low pressure (below 500 bars) and between 140 and $190^{\circ} \mathrm{C}$ (WinDomino modeling), while based on Liou et al. (1991), its temperature stability is between $140-170{ }^{\circ} \mathrm{C}$. The minimum temperature of the heulandite zone, examined in a number of boreholes in the geothermal areas of Iceland, is about $110-130{ }^{\circ} \mathrm{C}$. The fractures in the lapilli and in the massive basalt, where the minerals of Types 1 and 2 precipitated later, were presumably the results of early cooling of the rock shortly after volcanism in the area. Their cementation occurred at around $135-155{ }^{\circ} \mathrm{C}$ in the unconsolidated volcanoclastic sediment.

In Type 3 veins, the presence of prehnite indicates $\mathrm{T}=190-250^{\circ} \mathrm{C}$ calculated by WinDomino, and $200-380^{\circ} \mathrm{C}$ at low pressures ( $\left.<3 \mathrm{kbars}\right)$ according to Liou et al. (1991). Based on microthermometry, the minimum temperature of prehnite precipitation was between 130 and $181{ }^{\circ} \mathrm{C}\left(\mathrm{T}_{\mathrm{h}}\right)$, and according to the methane content of the aqueous inclusions, the Th values are very close to the true trapping temperature $\left(\mathrm{T}_{\text {trap }}\right)\left(\mathrm{min} .<10^{\circ} \mathrm{C}\right.$; Schubert et al. 2007). The following mineral is laumontite, which is the highest-temperature zeolite phase in the observed vein-filling sequence (Walker 1960; Hay 1978; Iijima 1988; Neuhoff et al. 1997; Jorgensen 2006). The average temperature of the laumontite zone examined in a number of boreholes in Iceland is about $190-230{ }^{\circ} \mathrm{C}$ (Jorgensen 2006), but it appears in every zone where the temperature is above $100{ }^{\circ} \mathrm{C}$ and below $300{ }^{\circ} \mathrm{C}$. Laumontite is stable between 100 and $225^{\circ} \mathrm{C}$ (WinDomino), and between 150 and $250{ }^{\circ} \mathrm{C}$ based on the experimental work of Liou et al. (1991). Assuming an open chemical system, decreasing $\mathrm{CO}_{2}$-fugacity may also play an important role during the precipitation of prehnite and laumontite (Liou et al. 1991; Juhász et al. 2002). While for laumontite precipitation low $\mathrm{CO}_{2}$-fugacity is required, for calcite a significantly higher $\mathrm{CO}_{2}$ content is advantageous in the fractures. Thomsonite is an index mineral of the low-temperature zeolite zones (Walker 1960; Neuhoff et al. 1997; Jorgensen 2006). The typical temperature of the thomsonite zone measured in many boreholes in Iceland is between 50 and $90{ }^{\circ} \mathrm{C}$, and this mineral always appears below $100{ }^{\circ} \mathrm{C}$ (Jorgensen 2006). The stability conditions of thomsonite cannot be modeled by DOMINO because heat capacity data are not available.

Concluding the thermal history of the fractured rock, during the cementation of veins Types 1 and 2 no significant change in temperature can be implied. The 
minerals precipitated in fractured lapilli before the final consolidation of the volcanic sediment at around $140-155^{\circ} \mathrm{C}$ (Type 1). The calcite of Type 2 crystallized in the fractures of basalt just following it was filled by altered volcanic material. The earliest cement phases in Type 3 veins from prehnite to thomsonite clearly suggest a cooling trend during fracture cementation from around $160{ }^{\circ} \mathrm{C}$ to $50-70{ }^{\circ} \mathrm{C}$. However, the next phases, crystals of late laumontite and chlorite aggregates among them, suggest an increasing temperature for the late evolution to the temperature of $150-225{ }^{\circ} \mathrm{C}$ on the basis of the temperature stability of laumontite. Based on chlorite thermometry data, reheating temperatures reached as high as $\sim 220^{\circ} \mathrm{C}$.

Laumontite is the most characteristic zeolite mineral in the whole Üllés-RuzsaBordány area. Although the present depth of the KBF is different in the two areas, the dominant vein type is the laumontite-calcite cemented Type 3 in both cases. These veins are typical between 2,530 and 2,900 meters of depth in the Ruzsa area, and between 2,200 and 2,650 meters of depth in the Üllés area. Compared to recent geothermal fields, a 700 meter-thick zone is usually not characterized by the presence of a single zeolite phase only. For the studied subaqueous volcanic sequence a burial diagenetic type of zeolite zonation is suggested instead. The present stratigraphic position of the volcanic rocks provides direct evidence for the subsidence being covered by more than 2,000 meters of Pannonian to younger sediments. On the other hand, the present borehole temperatures do not exceed $130-150{ }^{\circ} \mathrm{C}$, which is at least $70{ }^{\circ} \mathrm{C}$ lower than the calculated temperatures for the cementation of Type 3 veins. All these results suggest that after the basaltic complex subsided and reached its maximal temperature, it had to cool down. Detailed study of the complex effect of significant upraise, termination of postvolcanic hydrothermal activity and decreasing geothermal gradient in a more regional context is beyond the scope of the present paper. The lack of hydrocarbon inclusions in the first three vein types suggests that appearance of oil in the fractured system must postdate opening of new fractures and precipitation of Type 4 veins.

\section{Acknowledgements}

The authors thank MOL Ltd. for their financial support of the project, Balázs Kiss and Katalin Milota for their fruitful discussion and information, and András Nusszer and Bernadette Cs. Meszéna for thin sections. Special thanks go to Tamás Földes for the CT measurement. The comments of the two reviewers are also gratefully acknowledged.

\section{References}

Balázs, E., A. Nusszer 1987: Magyarország medenceterületeinek kunsági (pannóniai s. str.) emeletbeli vulkanizmusa (Unterpanno- nischer Vulkanismus der Beckengebiete Ungarns). Magyar Állami Földtani Intézet Évkönyve, 69, pp. 95-113. (In Hungarian.) 
Barth-Wirsching, U., H. Höller 1989: Experimental studies on zeolite formation conditions. - The European Journal of Mineralogy, 1, pp. 498-506.

Bons, P.D. 2000: The formation of veins and their microstructures. - Journal of Virtual Explorer, 2.

Bons, P.D. 2001: Development of crystal morphology during antitaxial growth in a progressively widening vein: I. The numerical model. - Journal of Structural Geology, 23, pp. 865-872.

Bons, P.D., M.W. Jessel 1997: Experimental simulation of the formation of fibrous veins by localised dissolution-precipitation creep. - Mineralogical Magazine, 61, pp. 53-63.

Bons, P.D., M. Montenari 2005: The formation of antitaxial calcite veins with well-developed fibers, Oppaminda Creek, South Australia. - Journal of Structural Geology, 27, pp. 231-248.

Cathelineau, M. 1988: Cation site occupancy in chlorites and illites as a function of temperature. Clay Minerals, 23, pp. 471-485.

Cathelineau, M., D. Nieva 1985: A chlorite solid solution geothermometer. The Los Azufres Geothermal System (Mexico). - Contrib. Mineral. Petr., 91, pp. 235-244.

Coombs, D.S., A.J. Ellis, W.S. Fyfe,. A.M. Taylor 1959: The zeolite facies, with comments on the interpretation of geothermal syntheses. - Geochimica et Cosmochimica Acta, 17, pp. 53-107.

Cserepesné, M.B. 1978: A Kiskunhalas-Ny-3. szénhidrogénkutató fúrással feltárt alsó-pannóniai bazalt és proterozoi migmatit képződményekről (About the Lower Pannonian basaltic and Proterozoic migmatite rocks drilled by Kiskunhalas-Ny-3 hydrocarbon exploration borehole). Földtani Közlöny, 108/1, pp. 53-64. (In Hungarian.)

Császár, G. 1997: Magyarország litosztratigráfiai alapegységei (The Lithostratigraphic Units of Hungary.). - Magyar Rétegtani Bizottság, Budapest.

De Capitani, C. 1994: Gleichgewichts-Phasendiagramme: Theorie und Software. - Beihefte zum European Journal of Mineralogy, 72. Jahrestagung der Deutschen Mineralogischen Gesellschaft, 6, pp. 48.

De Capitani, C., T.H. Brown 1987: The computation of chemical equilibrium in complex systems containing non-ideal solutions. - Geochimica et Cosmochima Acta, 51, pp. 2639-2652.

Gajdos, I., S. Pap, A. Somfai, L. Völgyi 1983: Az alföldi pannóniai (s. 1.) képződmények litosztratigráfiai egységei (Lithostratigraphic units of the Pannonian s. 1. formations in the Hungarian Plain). - MÁFI kiadvány, Budapest, pp. 28-33. (In Hungarian.)

Goldstein, R.H., TJ. Reynolds 1994: Systematics of fluid inclusions in diagenetic minerals. - SEPM Short Course 31., Society of Sedimentary Geology, 203 p.

Durney D.W., J.G. Ramsay 1973: Incremental strains measured by syntectonic crystal growth. - In: de Jong, K.A., R. Scholten (Eds): Gravity and Tectonics, Wiley, New York, pp. 67-96.

Fisher, D.M., S.L. Brantley 1992: Models of quartz overgrowth and vein formation: deformation and episodic fluid flow in an ancient subduction zone. - J. of Geophysical Research, 97, (B13), pp. 20043-20061.

Hanor, J.S. 1980: Dissolved methane in sedimentary brines; potential on the PVT properties of fluid inclusions. - Econimic Geology, 75, pp. 603-617.

Hay, R.L. 1978: Geologic occurrence of zeolites. - In: Sand, L.B., FA. Mumpton (Ed.): Natural Zeolites, Occurrence, Properties, Use. Pergamon Press, Oxford, pp. 135-143.

Hilgers, C., D. Koehn, P.D Bons., J.L. Urai 2001: Development of crystal morphology during unitaxial growth in a progressively widening vein: II. Numerical simulations of evolution of antitaxial fibrous veins. - Journal of Structural Geology, 23, pp. 873-885.

Holland, T.J.B., R. Powell 1998: An internally consistent thermodynamic data set for phases of petrological interest. - Journal of Metamorphic Geology, 16, pp. 309-343.

Humphris, S.E., G. Thompson 1978: Hydrothermal alteration of oceanic basalts by seawater. Geochimica et Cosmochimica Acta, 42, pp. 107-125.

Iijima, A. 1988: Application of zeolites to petroleum exploration. - In: Kalló, D., H.S. Sherry (Ed.): Occurrence, properties and utilization of natural zeolites. Akadémiai Kiadó, Budapest, pp. 29-37. 
Jovett, E.C. 1991: Fitting iron and magnesium into the hydrothermal chlorite geothermometer. GAC/MAC/SEG Joint Annual Meeting (Toronto, May 27-29, 1991) Program with Abstracts 16, A62.

Jorgensen, O. 2006: The regional distribution of zeolites in the basalts of the Faroe Islands and significance of zeolites as paleotemperature indicators. - In: Chalmers, J.A., R. Waagstei (Ed.) Scientific results from the deepened Lopra-1 borehole, Faroe Islands. Geological Survey of Denmark and Greenland Bulletin, 9, pp. 123-144.

Juhász, A., T.M. Tóth, K. Ramseyer, A. Matter 2002: Connected fluid evolution in fractured crystalline basement and overlying sediments, Pannonian Basin, SE Hungary. - Chemical Geology, 182, Akadémiai Kiadó, Budapest, pp. 91-120.

Kranidiotis, P., W.H. MacLean 1987: Systematics of chlorite alteration at the Phelps Dodge Massive Sulfide Deposit, Matagami, Quebec. - Economic Geology, 82, pp. 1898-1911.

Kretz, R. 1983: Symbols for rock-forming minerals. - American Mineralogist, 68, pp. 277-279.

Liou, J.G., C. De Capitani, M. Frey 1991: Zeolite equilibria in the system $\mathrm{CaAl}_{2} \mathrm{Si}_{2} \mathrm{O}_{8}-\mathrm{NaAlSi}_{3} \mathrm{O}_{8}-$ $\mathrm{SiO}_{2}-\mathrm{H}_{2} \mathrm{O}$. - New Zealand Journal of Geology and Geophysics, 34, pp. 293-301.

Magyar, I., Gy. Juhász, A. Szurominé Korecz, M. Sütőné SzentaiI 2004: A pannóniai Tótkomlósi Mészmárga Tagozat kifejlődése és kora a Battonya-pusztaföldvári-hátság környezetében (The Tótkomlós Calcareous Marl Member of the Lake Pannon sedimentary sequence in the Battonya-Pusztaföldvár region, SE Hungary). - Földtani Közlöny, 134/4, pp. 521-540. (In Hungarian with English abstract.)

Neuhoff, P.S., W.S. Watt, D.K. Bird, A.K. Pedersen 1997: Timing and structural relations of regional zeolite zones in basalts of the East Greenland continental margin. - Geology, 25, pp. 803-806.

Oliver, N.H.S., P.D. Bons 2001: Mechanisms of fluid-flow and fluid-rock interaction in fossil metamorphic hydrothermal systems inferred from vein-wallrock patterns, geometry and microstructure. - Geofluids, 1, pp. 137-162.

Pap, S. 1983: Alsó-pannóniai bazaltvulkanizmus Balástya és Üllés-Ruzsa-Zákányszék térségében (Lower Pannonian basalt volcanism in the Balástya and Üllés-Ruzsa-Zákányszék areas). Földtani Közlöny, 113/2, pp. 163-170. (In Hungarian.)

Ramsay, J.G., M.I. Huber 1987: The Techniques of Modern Structural Geology. Vol. 2: Folds and Fractures. - Academic Press Inc (London) Ltd. 392 p.

Rappensberger, Cs. 1991: Mineralogical identification of zeolites in a deep-drilling core. Thesis. Department of Mineralogy, University of Veszprém. 113 p.

Rivas-Sanchez, M.L., L.M. Alva-Valdivia, J. Arenas-Alatorre, J. Urrutia-Fucugauchi, M. RuizSandoval, M.A. Ramos-Molina 2006: Berthierine and chamosite hydrothermal: genetic guides in the Pena Colorada magnetite-bearing ore deposit, Mexico. - Earth Planets Space, 58, pp. 1389-1400.

Schubert, F, L.W. Diamond, T.M. Tóth 2007: Fluid-inclusion evidence of petroleum migration through a buried metamorphic dome in the Pannonian Basin, Hungary. - Chemical Geology, 244, pp. 357-381.

Shepherd, T. J., A.H. Rankin, D.H.L. Alderton 1985: A Practical Guide to Fluid Inclusion Studies. Blackie and Son Ltd., 239 p.

Walker, G.P.L. 1960: Zeolite zones and dike distribution in relation to the structure of the basalts in eastern Iceland. - Journal of Geology, 68, pp. 515-528.

Wheeler, R.S., P.R.L. Browne, K.A. Rogeres 2001: Iron-rich and iron-poor prehnites from Way Linggo epithermal Au-Ag deposit, southwest Sumatra, and the Heber geothermal field, California. Mineralogical Magazine, 65, pp. 397-406. 